\title{
Disenchantment, Buffering, and Spiritual Reductionism: A Pedagogy of Secularism for Counseling and Psychotherapy
}

\author{
Waleed Y. Sami *미 , John Mitchell Waters $\mathbb{1}$, Amelia Liadis, Aliza Lambert and Abigail H. Conley \\ School of Education, Virginia Commonwealth University, Richmond, VA 23284, USA; watersj3@vcu.edu (J.M.W.); \\ liadisa@vcu.edu (A.L.); ahweiss@vcu.edu (A.L.); ahconley@vcu.edu (A.H.C.) \\ * Correspondence: samiwy@vcu.edu
}

check for updates

Citation: Sami, Waleed Y., John Mitchell Waters, Amelia Liadis, Aliza Lambert, and Abigail H. Conley. 2021. Disenchantment, Buffering, and Spiritual Reductionism: A Pedagogy of Secularism for Counseling and Psychotherapy. Religions 12: 612. https://doi.org/10.3390/rel12080612

Academic Editors: Jesse Fox and Evan Copello

Received: 31 May 2021

Accepted: 3 August 2021

Published: 6 August 2021

Publisher's Note: MDPI stays neutral with regard to jurisdictional claims in published maps and institutional affiliations.

Copyright: (C) 2021 by the authors. Licensee MDPI, Basel, Switzerland. This article is an open access article distributed under the terms and conditions of the Creative Commons Attribution (CC BY) license (https:/ / creativecommons.org/licenses/by/ $4.0 /)$.

\begin{abstract}
The various mental health disciplines (e.g., counseling, psychology, social work) all mandate competence in working with clients from diverse religious and spiritual backgrounds. However, there is growing evidence that practitioners feel ill-equipped to meet the needs of their religiouslyand spiritually-diverse clients. Furthermore, formal education on religion and spirituality remains optional within coursework. Research on religion and spirituality is also noted for its reductionism to observable outcomes, leaving much of its nuance uncovered. This paper will utilize philosophies of secularism and explore the concepts of disenchantment, buffering, and coercion, to help illuminate why our contemporary society and our disciplines struggle with this incongruence between stated values and implementation. Case vignettes and recommendations will be provided to help practitioners and educators.
\end{abstract}

Keywords: secularism; religion; spirituality; psychotherapy; counseling

\section{Introduction}

Research across many health disciplines affirms religion and spirituality are an important element for physical and mental health, including medicine (e.g., Demir 2019; D'Souza 2007; Isaac et al. 2016), social work (e.g., Oxhandler et al. 2015), counseling (e.g., Diallo et al. 2021; Stewart-Sicking et al. 2017), and psychology (e.g., Oxhandler and Parrish 2018). In recent years, there has been an increased focus on religion and spirituality in mental health care, including counseling or psychotherapy (e.g., Captari et al. 2018; Cashwell and Young 2014; Stewart-Sicking et al. 2017; Rupert et al. 2019). This growing body of literature on evidenced-based and spiritually integrated psychotherapies (SIPs) highlights the need to include spirituality and religion in counselor training so that clinicians may better serve their current and future clients and patients (Captari et al. 2018; Currier et al. 2021; Diallo et al. 2021; Dobmeier and Reiner 2012; Oxhandler and Parrish 2018).

In the last decade, formal structures across disciplines have been constructed out of this need. Accrediting bodies have recognized religious and spiritual beliefs as a key component of diversity (APA 2015; CACREP 2015; COAMFTE 2016; CSWE 2015). The Association for Spiritual, Ethical, and Religious Issues in Counseling's (ASERVIC), a division of the American Counseling Association (ACA), released the Competencies for Addressing Spiritual and Religious Issues in Counseling (2009). These competencies were specifically dedicated to addressing religion and spirituality in research, education, and clinical practice. Similarly, Vieten et al. (2016) released the Competencies for Psychologists in the Domains of Religion and Spirituality as a guide for practitioners.

These competencies are the standard for clinician competency for working with clients from diverse religious and spiritual affiliations. They emphasize the importance of mental health professionals' ability to understand the difference between various world religions, spiritual systems, agnosticism, atheism, and provide a framework for addressing religion and spirituality in clinical practice. Additionally, the competencies stress the importance of clinician self-awareness regarding their own beliefs and how that might influence the 
therapeutic relationship. Mental health professionals are to take the client's beliefs and practices into consideration when performing virtually any duty of a counselor including assessments, making decisions about diagnoses, and treatment planning (ASERVIC 2009; Vieten et al. 2016). These competencies have created an additional standard that clinicians should work toward in order to facilitate growth, healing, wellness, and symptom reduction in the clients and communities they serve.

Even with these competencies in place, mental health professions, in general, have fallen short with sufficiently addressing religious and spiritual identities in practice and education. Although disciplines that provide psychotherapy agree about the importance of addressing religion and spirituality, many clinicians report feeling unprepared to implement religious/spiritual competencies in practice (Dobmeier and Reiner 2012; Isaac et al. 2016; Robertson 2010), discomfort with working with clients of diverse religious identities (Hage et al. 2006; Hofmann and Walach 2011), and have reported their interest in obtaining training in these areas (Delaney et al. 2013; Souza 2002; Oxhandler and Parrish 2018; Young et al. 2007). Additionally, there appears to be some evidence that religion and spirituality are rarely discussed in counseling and psychotherapy educational programs (Brawer et al. 2002; Cornish et al. 2012; Hage et al. 2006; Johns 2017; Schafer et al. 2011; Scott et al. 2016; Walker et al. 2004). Furthermore, many mental health educational programs inconsistently address topics of religion and spirituality (Cashwell and Young 2014; Dobmeier and Reiner 2012; Hage et al. 2006; Oxhandler and Parrish 2018; Post and Wade 2009; Walker et al. 2004; Vieten et al. 2016; Young et al. 2007). One consequence, among many, of the lack of education, is that there is evidence to support the claim that counselors tend to psychopathologize religious or spiritual beliefs and practices they are not familiar with (Allmon 2013; O'Connor and Vandenberg 2005). For example, if a client reports a mystical experience (i.e., a Christian feels a sense of oneness or union with God or a Hindu experience that Atman is Brahman, or that the self/soul is identical with the eternal, absolute being), a clinician could pathologize it as a hallucination or a symptom of psychosis. Although the Diagnostic and Statistical Manual of Mental Disorders (DSM-V; American Psychiatric Association 2013) does not formally allow for clinicians to diagnose clients with a psychosis on the basis of religious experience, the studies above have shown that this is actually a common occurrence.

In the arena of higher education and counselor training, a novel study by Anekstein et al. (2018) explored the experiences of religiously and spiritually-diverse doctoral students in four counselor education and supervision programs. These participants all identified as young women, and were of diverse religious and spiritual backgrounds, such as Buddhism, Mormonism, and Native American traditional beliefs. The researchers found that religious counselor education doctoral students in the sample regularly experienced four themes in their doctoral training: misunderstood, judgment, stuck, and not fit for the profession. These feelings, which may be common across students with diverse religious beliefs, were related to the impact of the assumptions of others, feeling invisible, a lack of support, and feeling disheartened and stunted. The painful message of not fit for the profession described both the covert and overt attitudes and messages received that their religious beliefs are incompatible with the counseling profession. The students in the sample frequently felt that hiding their religious identities from others was the safest path forward, due to the judgment or exclusion they could experience if colleagues or professors knew. Some of these results within CES could be explained by (Adams et al. 2014). The researchers noted that the barriers that stood between integration and teaching of religion and spirituality within training programs rested on various dynamics, such as lack of faculty knowledge, faculty disinterest, seeing religion/spirituality as simply cultural identity, and faculty bias and resistance, among other trends.

The current state of religion and spirituality in counseling and psychotherapy highlights a sharp contradiction. There is a disconnect between a discipline's stated values (i.e., religious and spiritual competency) and the evidence of actual practice (i.e., limited education or training on SIPs, psychopathologizing religious beliefs, wariness of working 
with clients who hold diverse religious and spiritual beliefs). To develop a deeper understanding of these inconsistencies, incongruencies, and contradictions, it is important to explore the historical and theoretical concepts that have created these conditions. Therefore, we will begin by reviewing theories of secularization. These theories can help provide a larger, macro-level insight into the cultural and national trends of our contemporary society. These trends inevitably shape how religion and spirituality are conceptualized, taught, and expressed within professional settings. We will then explore and interrogate how their principles apply to mental health training and clinical practice. Next, we will provide case studies that describe concretely how theories of secularization show up in mental health education, clinical supervision, and clinical practice. Finally, we will conclude with implications and recommendations for education, supervision, and clinical practice in light of these theories.

\section{Contemporary Secularism}

To develop a deeper understanding of these contradictions, it is important to explore the historical and theoretical concepts that have created these conditions. Religious observance has declined in importance among younger generations of Americans (Pew Research Center 2019). A plurality of millennials now identifies as having no religious affiliation, colloquially called nones. Similarly, many millennials regard themselves as spiritual but not religious. Fewer Americans today attend religious services, mention praying, or regard religion as important in their lives (Pew Research Center 2021). However, this picture is nuanced by race and ethnicity, religious identity, and political affiliation. Black and Hispanic millennials are still more likely to identify as Christian, than their white peers (Pew Research Center 2019). Similarly, racial and religious minorities of various other faiths (e.g., Islam, Hinduism, Sikhism) are less likely to report this disparity and change over the generations. Americans who identify as Democrats are less likely to report religious affiliation and observance, than Republicans (Pew Research Center 2019). Therefore, the drop of religious observance and affiliation appears to be most concentrated among white, Democratic, and younger generations. Beyond the United States, secularization is part of a global trend towards restriction of religious observance (Majumdar and Villa 2020). Some of these restrictions are targeting minority religious groups within the nation (e.g., Saudi Arabia, Armenia, India), or hostile to all forms of overt religious expression (e.g., China, Belarus), (Majumdar and Villa 2020). Many diverse countries that are dissimilar in culture and national histories are nevertheless, restricting forms of religious observance for minority groups, or against religion in general. While diverse from each other, they are characterized by sharing forms of political authoritarianism, which restricts the human rights of their citizens (Majumdar and Villa 2020).

Majumdar and Villa (2020) argue that social hostility towards minority faiths in nations that are democratic (e.g., United Kingdom, Denmark), is also an accurate way to judge intolerance towards minority religious groups. Within these nations, intolerance often stems from secular reasons (e.g., incompatibility with liberal values, national security). Regardless of intention, the growing intolerance around the world towards various religions, combined with the increasing secularism in the United States in the contemporary moment, challenges us to understand the complex role religion and spirituality play in society. The social and political context around religion and spirituality complicates professional clinical work and education.

Within the context of increasing secularism and the trend toward less religious observance in the United States, there is simultaneously increased attention within the mental health professions to explore the roles religion and spirituality play in client's lives through practitioner competence with SIPs. Yet the gap between training and practice persists, with religious and spiritual competencies inconsistently taught in clinical training. As mentioned earlier, there is still a lot to learn about what is behind Anekstein et al. (2018)'s dynamic of counseling students feeling misunderstood, judged, or unfit for the profession. Furthermore, Post et al. (2014) describes the contradictions of young college students in 
group counseling, who believe religion and spirituality is an appropriate topic for group counseling, but only a minority agree with bringing those concerns to the group. While there are instances of overt discrimination and marginalization that social justice and ethical frameworks can address, insight into why practitioners feel incongruence between their religious, spiritual, and professionalidentity is lacking. To address this disparity with nuance, theories from various disciplines (e.g., sociology, philosophy, religious studies), that concern themselves with concepts of secularization, will be utilized to provide a theoretical framework to investigate this disparity between values and implementation within mental health professions. These theoretical insights will aid practitioners and educators in understanding the diversity of secularism and its impact on clients and students. Furthermore, it will aid professionals in understanding the lived experiences and contradictors of students and clients with diverse religion and spirituality backgrounds. The authors will focus on how a secular frame teaching and understanding religion and spirituality, promotes an over-focus on measurable outcomes. This focus restricts the broader engagement with religion and spirituality, leading to dissonance and lack training and fit between diverse students, clients, and educators within the mental health professions.

\section{What Is Secularism?}

Secularism's definitional structure is complex and multifaceted. The National Secular Society, a non-profit education center in the United Kingdom, conceptualizes secularism in three major ways: (a) separation of religious institutions from state institutions, (b) freedom to practice a faith without imposing it on others, or being imposed on, and (c) equality, where one's religious views don't disadvantage them in society (National Secular Society 2017). As the definition implies, secularism operates on a spectrum that inhabits the political, structural, and cultural. Therefore, scholars have pushed back on the simplistic notion that secularism simply means a separation of church and state, and that it also has its own interpersonal and cultural modes of being that are reproduced in culture (Asad 2003; Calhoun 2010). Indeed, secularism's political manifestations are also diverse. For example, there are more pluralist conceptions of secularism practiced by the United States and India, which recognize a multiplicity of religious diversity in its citizenry (Calhoun 2010). On the other hand, France's conception of laïcité, and the modern republic of Turkey's laiklik, practices a firm form of secularism, that historically inhibits religious expression in public spaces, such as restricting women who wear hijab from public schools (Calhoun 2010; Hancock 2008; Somer 2013). Secularism must be understood as a form of political and cultural commitments that are dynamic, and open to negotiation and friction within a society. Discussions of spirituality and religion can vary widely in counselor training programs based in unique situatedness socially and culturally. For example, there are CACREP-accredited programs at religious affiliated institutions, as well as non-religiously affiliated. Additionally, private versus public institutions may have different approaches in discussing religion, while still maintaining the bounds of CACREP. Therefore, cultural and national context will influence the make-up of the student body, and the boundaries and norms of discussion and training. Furthermore, many students are in the Individuative-Reflective stage of faith development, as noted by Fowler (1981) during their studies. This stage is marked by assimilating diverse values that can contradict religious and spiritual upbringing, which can create dissonance. Similarly, students may have had instances of spiritual abuse by trusted authorities, or believe that traditional religions cannot accommodate liberal values around LGBTQ+ rights and feminism. Indeed, Putnam and Campbell (2012), state that the politicization of religion in America over the last several generations has created a polarized dynamic, as the religious become more religious and the secular become more secular. This sharp polarization increasingly splits communities into echo chambers with little social interaction and few close relationships. Secularism and its theories should not be overdetermined to the point of predicting an individual student or professional's potential discomfort with issues around religion and spirituality. Rather, they are useful theoretical models to understand how institutions and 
culture reproduce certain ideas of religion and spirituality, and how that can be of service or disservice to diverse clients and students.

\section{Secularism as Theory}

The journey of Western civilization towards secularism has been described as disenchantment, by noted sociologist Max Weber (Jenkins 2000; Weber and Parsons 2017; Weber and Fischoff 1993). Disenchantment is Weber's conception of the process in how Western societies privileged scientific forms of rationality, understanding, order, and bureaucratic cause-and-effect relationships, that were products of its Enlightenment and Protestant legacies (Jenkins 2000). This is contrasted with the enchantment of traditional societies, that valued belief before empirical measurement. This belief allowed traditional societies to saturate every moment in the environment and their personal lives, with supra-rational meaning, purpose, and the sublime. Disenchantment followed the heightened ability to pursue empiricism in Western societies, as knowledge became noted for its reductionism, technical expertise, and disciplinary specialization (Weber et al. 2020). Indeed, Calhoun (2010) notes that the various disciplines that make up the social sciences (of which, mental health practitioners are a part), are a part of the secular process, divorcing themselves from moral philosophy and theology in the 19th century, to gain status as disciplinary forms of scientific knowledge, and empiricism. While humanity gained forms of control and knowledge specialization through this form of empiricism, the reductionism inevitably led to disenchantment. This disenchantment, as Weber argues, follows an understanding of the world as rationally derived from measurable cause-and-effect relationships, and locks the individual into an iron cage. This iron cage improves bureaucracy and efficiency, but causes loss of autonomy and disenchantment with the world (Weber et al. 2020). While Eurocentric (although other cultures have valued empiricism as well), Weber does illuminate notions of value-fragmentation and the disenchantment, which help describe the process of religion secularizing into forms of measurable choices of belief and coping, as simply a reductionist epistemological option in Western culture (Mahmood 2010). Belief and coping are easy to measure empirically, but understanding religion and spirituality as just being made up of these measurable essences, reduces the subjective and lived experiences of those engaged in these practices. Additionally, it becomes difficult under a rational and disenchanted secular paradigm to measure how religion and spirituality can impact other areas of life, such as moral demands, asceticism, and forms of mysticism (Weber and Fischoff 1993).

Disenchantment and the impact of secularism on religion and spirituality is debated, with some authors arguing that the West hasn't necessarily been disenchanted, as has been theorized in the past. Indeed, Latour and Porter (1993), argue that the integration of science, with other political institutions creates forms of hybrid culture that individuals place faith in, and thus are "enchanted" in contemporary society. Furthermore, Josephson-Storm (2017) opposes the disenchantment theory, separating it from secularization. While the West has secularized, its populations have not been disenchanted to the level theorists have argued. Individuals still believe in the paranormal, engage in occult and spiritual practices, along with carrying conceptions around fate and destiny that are congruent with traditional societies (Josephson-Storm 2017). Nevertheless, disenchantment and secularism are useful theoretical concepts to understand, as they provide insight in how religion and spirituality are investigated and taught in academic disciplines.

Building on the idea of disenchantment, in A Secular Age, Charles Taylor (2018), notes that the process of disenchantment thus changes the character of institutions of law, art, and other forms of culture, not only impacting politics. This transformation and disenchantment have transitioned religion from its cultural web of enchanted connections with forces beyond the control of the interpersonal self, into a set of beliefs around cosmology, and thus an object of empirical inquiry (Mahmood 2010). This disenchantment leads to individuals living as buffered selves (Taylor 2018), where beliefs, values, and behaviors are bracketed and controlled, within an individual and private cognitive domain of self. This buffered self is 
characterized by a reductionist view of self, made of its constituent and material essences within a disenchanted society. This buffering leads to disembedding, which is characterized as removing the self from traditional webs of interpersonal relationality and cosmology (Taylor 2018). Thus, in Anekstein et al. (2018)'s description of counselor education doctoral students feeling a lack of fit, we see clear descriptions of buffered selves negotiating their disembedding from a professional discipline.

If one's intuitive and subjective forms of religion and spirituality don't always manifest neatly into measurable, reductionist outcomes of coping, then one must buffer and disembed, and withdraw parts of their lives from secular society at large. Crucially, this buffered self is contrasted with Taylor's (2018) conception of the porous self, or the self-identity that is open to enchantment and the sublime. This buffered self disemebeds, and leads to clear splits between the mind, body, and world (Taylor 2018). Loss of meaning inevitably occurs, as the self's conception of religion and spirituality becomes more privatized and divorced from a sense of coherent cosmology. These splits helped to create the cleavage of spirituality from religion in the West, allowing it to become an individual and private belief, sequestered from the traditional cultural web (Ammerman 2013). Notably, this type of belief is considered creedal, which is contrasted with a pre-traditional understanding of belief that was more porous, instead of regimented and constrained (Taylor 2018) Indeed, this buffering leads to the divorce of spirituality from religion, and situates this within the modern West as its own form of culture that shares porous boundaries with traditional religion (Ammerman 2013). This divorce of spirituality and religion (that follows inevitable buffering), would be foreign to traditional societies, but is increasingly becoming universal in its designation (Singh 2019) Indeed Heelas (2011), presents an overview of the unique integrations of spirituality and the self, and their relationship with traditional religions as contemporary individuals negotiate the loss of tradition. Furthermore, Taylor (2018) argues that forms of occult and divination are attempts by modern individuals to recover the sense of porousness, and to resist buffering. These forms of individual spirituality sacralize the self, as many Westerners detraditionalize from various Christian affiliations (Houtman and Aupers 2007). These complex interactions and dynamics create the environment for religion and spirituality to become seen as privatized forms of creedal belief or behavioral coping that promotes subjective wellness. Thus, religion and spirituality's disenchantment results in both ideas being conceptually limited to empirical and rational paradigms, that individuals must privatize and buffer, at the expense of encountering religion and spirituality from the porous self.

\section{Institutional Coercion}

Disenchantment and buffered selves are the sentimental and phenomenological ways of being in a secularized society, but both Taylor and Weber miss the political dimension of secularism. In this vein, Asad (2003), argues that secularism not only means the political division of church and state, but rather, the prerogative to define and regulate how religiosity is practiced and conceptualized. Simply put, institutions reproduce cultural and behavioral norms they value. Under these institutions, what religion and spirituality is and are, and how they can be manifested professionally, will be reproduced and normed through selection. Thus, institutions drive the buffering process by selecting forms of religious and spiritual behavior they value, but placing boundaries around those they may not. For example, a religious ritual that conflicts with secular work requirements (e.g., praying instead of going to a work meeting), will impose professional repercussions on the worker. Thus, the worker must make choices between how their faith is expressed or minimized to adapt to dynamic secular requirements. Indeed, as Asad notes, this reproduction can become inadvertent or unintentional, nevertheless it is reproduced as the boundaries around what religion is and how it can be expressed, become calcified over the generations.

This is a crucial distinction, as it is normative observation of how our institutions select for certain, professional behavior. Asad (2003), notes that normative understandings of religion are not simply enforced through a formal government and law, but also through 
non-state civic and cultural institutions, such as public universities, schools, and non-profit voluntary organizations. This dynamic interplay with state and non-state powers in a society to regulate, promote, or remove forms of religion, often manifest in contradictory principles and thus become conflicts over power (Asad 2003). Asad argues that the state and various cultural institutions are never neutral, and they can coerce the behavior they want through selecting for social and professional norms. Describing their contours, Asad notes:

... the secular' should not be thought of as the space in which real human life gradually emancipates itself from the controlling power of 'religion' and thus achieves the latter's relocation. It is this assumption that allows us to think of religion as 'infecting' the secular domain or as replicating within it the structure of theological concepts ... Secularism doesn't simply insist that religious practice and belief be confined to a space where they cannot threaten political stability or the liberties of 'free-thinking' citizens. Secularism builds on a particular conception of the world. (Asad 2003, p. 191)

This conception of the world can be as coercive or contradictory as hegemonic religious ideology can be, or it can be tolerant. This dynamism helps explain why experiments of secularism in different countries have led to such drastic, differing results for their populations. Returning to the conceptual definition provided by the National Secular National Secular Society (2017), equality and separation can be two, politically opposing ideas that create contradictions over power (Asad 2003). Higher education settings and public institutions in the United States are called on to provide competencies around spirituality and religion, while not privileging one religious and spiritual perspective. However, this subtle and discriminating line is difficult to implement in practice without formal education and supervision around the complexity of religion and spirituality. This contradiction leads to certain norms and behaviors around religion and spirituality that communicate acceptable boundaries of discussion. For example, religion and spirituality may only be discussed in reductionistic ways that are "safe" and won't lead to conflicts over world-views, such as a focus on coping and meaning-making. However, this leads to many students and practitioners feeling ill-prepared to implement competencies (Dobmeier and Reiner 2012; Isaac et al. 2016). These dynamics help explain the lack of fit, and judgment noted by the students in Anekstein et al. (2018) or the contradictions seen in Post et al. (2014)'s study of students in group counseling.

Furthermore, higher education attainment within the United States is characterized by its secular make up, with a plurality of individuals with postgraduate degrees identifying as secular or "no religious belief" (Ecklund et al. 2008; Thalheimer 1973). Thus, in utilizing Asad (2003)'s framework, mental health educators must balance teaching disenchanted versions of religion and spirituality in coercive institutions that are built on reproducing acceptable versions of religion and spirituality. This inherent contradiction provides us an understanding for how students with religious backgrounds find it difficult to "fit into" their institutions and professional identities. Similarly, it highlights the challenges that educators face in providing competence and background into religion and spirituality, in all of its complex dimensions. The authors will highlight the concrete application of these various secular theories in the vignette section. These vignettes are built on the themes highlighted by Anekstein et al. (2018), Adams et al. (2014), and the author's personal experiences in professional and educational settings.

\section{Vignette-Jordan}

Jordan is a Chinese-American Master's student in the second year of an accredited counseling program in the United States. Jordan has been grappling with experiences during the COVID-19 pandemic, including how American society has framed responsibility for the virus around Chinese individuals. Additionally, Jordan has been struggling with the various national and international social justice movements that are highlighting interpersonal and governmental oppression. It is difficult for them to reconcile ideas of divine mercy and justice with the trauma and terror experienced by individuals all over 
the world. These experiences have caused inner dissonance in Jordan, resulting in a sense of doubt and loss. They are nervous to bring attention to these issues in the classroom but acknowledge that it weighs on them heavily. These interpersonal and intellectual challenges mirror Perry's (1970) developmental stage of multiplicity, and Fowler (1981)'s stage of faith development as individuative-reflective faith. Both theories state that the early adulthood years revolve around issues of integrating diverse sources of meaning, different information, and alternative worldviews into their pre-existing values.

Jordan was raised Seventh-Day Adventist (SDA), a sect of Protestant Christianity, by their parents. However, as a result of some of their personal reflections, Jordan has more recently started to identify as spiritual but not religious. They have been thinking about how their shift in identity may be connected to recent events. They are struggling to see how their religious upbringing can be reconciled with new perspectives and norms encouraged in their profession.

\subsection{Example 1-Classroom Dynamics}

This semester, there has been a recent uptick of hate and bias motivated violence against Asian American and Pacific Islander (AAPI) communities in the United States. The media reports that there has been a correlation with these attacks and blame for the spread of COVID-19. To fuel these sentiments, some media outlets and government officials have gone as far as calling COVID-19, The Chinese Virus. To see this, unfold has been frightening for Jordan. They are especially worried about their parents being targeted. Jordan discourages their mother and father from going to places like their church, a social institution that is important to their parents. However, churches and religious institutions have long been victims of violence and racism within the United States, and Jordan is frightened for their safety. Their parents remark that nothing will prevent them from observing the Vespers, or prayers, before the Sabbath, the day of rest.

While their counseling program discusses being an advocate for their client, and the importance of social justice, Jordan feels that their program has been dismissive of how current events are impacting AAPI students in complex ways. Jordan's professor, who is the chair of the program, has traditionally been seen by students as someone who is highly regarded. Many students look to this professor as an ally. Recently, the class received an email from the professor that states, "Thinking of you all during this time. I have faith in our country to find a vaccine. I am looking forward to a restored sense of safety in the classroom. Please check in with our AAPI students."

Jordan recognizes that the show of support from faculty is well-intentioned and in good-faith. However, Jordan's fear of their parent's vulnerability at their church keeps them apprehensive. Additionally, the unique identity of being Chinese-American and SDA is challenging to articulate in a class-room and the wider faculty. Jordan notes that there is support for minority racial identities in the program, but not as much for religious minorities, nor their unique intersections. From these subtle messages, Jordan notes that it may not be appropriate to bring up their parent's religious identity, and how that complicates the current social crisis. Additionally, they are struggling with their adherence to the religion they were raised in, and are wondering how that will impact their clinical work.

Jordan decides to bring up these issues one day in the professor's classroom with their peers. They receive support from their peers and professors over their concerns about their racial identity in the current climate. However, they are met with silence when they try to discuss their parent's experience with their faith, and how they utilize the observance of various dietary laws and Vespers before Sabbath, to help promote community resilience. Jordan detects a lack of curiosity from their peers when bringing up this religious doctrine, compared to reflections about their Chinese identity. The professor remarks that it "seems like a good form of coping," before moving on to the next portion of the class. Jordan feels dismissed, however unintentionally by their class and professor. While they may not practice their parent's religion, they are also aware that these specific rituals resonate powerfully in ways that are indescribable. They feel that these rituals were 
inadvertently reduced to forms of coping by their professor, no different than other clinical recommendations, such as taking a walk, exercising, or playing with a pet. However, there is no formal space to explore these dimensions within the classroom. Due to these messages received, Jordan begins to buffer and disembed by slowly splitting off parts of themselves from others in the profession, realizing that they won't be recognized amongst their colleagues and peers.

\subsection{Example 2-Supervision Dynamics}

Jordan is currently enrolled in a counseling practicum course which requires a field placement. They work with clients at a university and videotape their counseling sessions to gain feedback on their tapes in class. Jordan's supervision includes a supervisor for the class who is the chair of the program mentioned above, and two other counselorsin-training (CITs). In class, Jordan shows a video of a client bringing up their religious identity in the session. When commenting about the clip, Jordan notes that they were not feeling confident in how to talk about religion with the client, and ended up glossing over it. Jordan is struggling with their prior experience of how religion and spirituality are discussed in the classroom, and what is appropriate to bring up, or what is not.

Jordan asks for feedback from the supervisor and CITs about how to address this with the client moving forward. The supervisor notes that the client is struggling with their faith, because it is creating demands on their life, rather than helping the client feel better. One CIT notes how oppressive religious doctrine can be, and wonders if practitioners should actively confront their clients from a position of social justice. Jordan however, interprets these moral demands as part and parcel of how one must reconcile what they wish, with what God wishes, which symbolizes an internal battle with self. Jordan's instinct is to let the client continue to struggle with this dynamic with empathy. However, their supervisor and classmates interpret this as oppressive and an unhelpful form of spirituality, and recommend that Jordan speak to the client about alternative ways to cope or to even explore if religion and spirituality is a good option for them. Jordan ends up more confused about how to integrate these complex and contradictory ideas of religion and spirituality with their client, and ultimately pretends to understand and agree with their supervisor, in order to end their time together and move on. The other CITs show their supervision tapes to finish up the class.

At the end of class, a student puts in the online chat that they, and a few other classmates, are staying on for a happy hour and that all are free to join. The professor says "this is a great opportunity to build community and really become friends with each other. You all should participate." Even though Jordan now identifies as more spiritual than religious, they were still raised as SDA and refrain from drinking alcohol. Since Jordan was already feeling uncomfortable and distant, they say: "Sorry, I don't think I have time tonight."

Jordan recognizes that forms of social and professional progress, such as getting together for drinks, are built around norms that will be difficult for them to fit under. This coincides with Anekstein et al. (2018)'s themes of judgement and lack of fit felt by many religious and spiritual students. Jordan wonders how much buffering they must do in order to acculturate into the social norms of their profession and what forms of religion and spirituality they must separate. This dynamic was noted by Asad (2003), in how cultural institutions norm and coerce the behavior they expect to see, bracketing and reproducing what it means to be religious and spiritual. Notably, there is no overt coercion in the sense that Jordan must adopt a certain label, or even drop their identity as SDA. However, due to the secular norms of these institutions, they inevitably select and promote the types of practice behavior that are expected. Thus, this form of coercion is achieved not through forcing Jordan to remove the SDA identity, but through encouraging Jordan not to be a certain type of SDA, or religious and spiritual person. 


\section{Vignette: Nasim}

Nasim is a 15-year-old individual that is seeing a counselor for depression and family issues. Nasim has been seeing their counselor for a few weeks and the two have generally gotten along well. Nasim and their family identify as Muslim and they are currently observing Ramadan, a period of fasting and prayer that is considered to be one of the holiest months of the year. During this period of fasting, the counselor begins to notice that some of Nasim's depressive symptoms, such as fatigue and lack of sleep, have increased and the counselor becomes concerned. Nasim explains the various rituals and practices they and their family observe during Ramadan, including fasting from food and water until sundown every day. The counselor is unfamiliar with Islam and its various practices and traditions. Furthermore, the counselor never encountered formal education around religious and spiritual practices, including those that are ascetic in nature. When religion was discussed in their training, it was mainly framed as a resource for coping. Coping, however, in the counselor's mind, is intended to reduce symptoms, rather than exacerbate them.

The counselor begins exploring Nasim's symptoms with them and considers the possibility that the fatigue might be attributed to the fasting that is practiced by Nasim and their family. The counselor is now struggling, not only with the usefulness of their client's religious and spiritual practices, but the damage it might be doing to them. Thus, the counselor inadvertently participates in the reductionist understanding of religion and spirituality in a disenchanted society.

The counselor, also knowing about the relational strains between Nasim and their family, begins to ask them questions, given their depression, about whether they actually want to participate in fasting and asks if their family is pressuring them to do this. Nasim denies that they are being pressured and that they actually want to practice fasting for Ramadan. Concerned about increasing depressive symptoms and the possibility of Nasim experiencing suicidal ideation, the counselor continues to ask questions about pressure from family, and Nasim continues to deny.

Nasim, feeling misunderstood and unheard by their counselor, begins to disengage from this topic. They then begin to buffer and disembed, and bracket their beliefs by changing the subject to something that feels safer. Nasim recognizes that the counselor's worldview can't conceive of religious and spiritual practice that would challenge their ability to live and work within the larger, secular society. The counselor asks why can't fasting simply be done outside of school hours or at home, feeling the need to challenge distortions in the client. Nasim changes the topic to something safer, and decides they won't be able to bring up their religious and spiritual identity to their sessions.

Nasim learned that moving forward, their religious beliefs and practices must be set aside and that the way the counselor will deem that they are "mentally healthy" is for them to not bring that part of themselves into future sessions. Crucially, the counselor appears to have only been able to conceptualize religious/spiritual practice as forms of coping, due to their training within formal education, which emphasizes measurable and empirical outcomes. Had they been taught that religion and spirituality also involve subjective, spiritual knowledge gained from ascetic spiritual practice, they may have been more open to continuing to learn the diverse ways that religion and spirituality influence a client's life in ways that are not typically measurable.

\section{Recommendations and Conclusions}

Practitioners, educators, and supervisors within the various psychotherapy fields will benefit from examining the different theoretical ideas of secularism described in this manuscript. Developing theoretical rigor behind how religion and spirituality are manifested, understood, and ultimately regulated and promoted within an increasingly secular country, allows for greater nuance within our practice and better clinical outcomes. Furthermore, while the United States continues to secularize. This process is unevenly complicated through the various forms of political, cultural, and racial identities in a diverse society. Within this context, professionals will struggle to conceptualize and uphold 
their ethical duties to clients and fellow colleagues whose lives are engaged with religion and spirituality. The evidence provided thus far, illuminates how medical and helping professions' ethical mandates are unevenly applied, thus manifesting in their student's trepidation with diverse religion and spirituality in the field. Furthermore, the findings in Anekstein et al. (2018) demonstrated that students that do hope to integrate religious and spiritual identities and competencies as practitioners, receive messages of incongruence and judgment from their colleagues and professors. From an intersectional standpoint, this dynamic can be further complicated through latent racism that exists against religious minorities in society. The spectrum of harm could range from microinvalidations, subtle and overt messages of lack of belonging, to outright discrimination against certain minority faiths and spiritual perspectives. This will generate an enormous cost on the various psychotherapy disciplines, as they will struggle to diversify their student pools in order to meet social needs.

The experiences of various students and professionals are not all the same. It is salient to conclude that a variety of social identities (e.g., sexuality, immigration status, ethnicity, gender) will impact how students navigate their relationships with religion and spirituality within training programs and in professional work. Indeed, as noted above, secularism's impact is unevenly felt amongst different generations, race and ethnicity, religious and political affiliations. Therefore, it may be difficult to disentangle different forms of potential marginalization from the larger paradigm of contemporary secularization. However, the evidence of incongruence (Anekstein et al. 2018; Post et al. 2014), the disparities in lack of training (Dobmeier and Reiner 2012), lack of faculty training and bias (Adams et al. 2014), and discomfort working with religious diversity (Hofmann and Walach 2011), require fresh theoretical insights. It is useful for educators and professionals to reflect on the dynamic impact of secularism over time, in order to help explain how these aforementioned contradictions continue to manifest within the psychotherapy fields.

The authors of this manuscript have utilized three major philosophical insights on secularism from Max Weber, Charles Taylor, and Talal Asad, to help demonstrate why religious and spiritual disparities exist, and how they are reproduced in modern society. However, several steps can be taken to improve the various psychotherapy disciplines' ability to work with diverse manifestations of religion and spirituality, and diversify professional ranks with talented practitioners.

Researchers can start to critically examine, question, and interrogate how religion and spirituality are currently defined and operationalized. Reductionist and measurable understandings of religion and spirituality, while important, cannot possibly convey the deep richness, nuance, and complexity of these vital concepts. Researchers can interrogate some of the secular theories provided and attempt to operationalize religion and spirituality through a more complex lens, adding to the knowledge base of practitioners. Within contemporary research, novel developments in the study of religion, spirituality, and atheism are leading to complex and multi-faceted insights that push against common ideas of reductionism. Indeed, The Psychology of Religion by Vassilis Saroglou covers different research-backed findings on religion and spirituality that offers empirical research behind the dynamics of spirituality, atheism, and other manifestations (Saroglou 2020). This book will aid researchers and educators within the discipline in bringing an empirical discussion to some of the trends highlighted in this paper.

Within the classroom, much can be done to improve the status of religion and spirituality. Despite being a competency within various ethical mandates of our disciplines, there is currently no requirement to teach religion and spirituality courses. This is the contradiction of the ASERVIC competences, which mandate competence with no requirement for formal training. With the increasing secularization of faculty and students in higher education, there is a strong chance that practitioners will continue to struggle with diverse populations, due to lack of exposure and training. The authors advocate for including mandatory course-work on the sociology of religion and spirituality, including some of the theories of secularism noted within the theoretical section of this paper. Devoting 
more coursework around different sorts of religious and spiritual experiences, along with contemporary discussions of the role of religion within an increasingly secular America, would help better prepare students for broaching complex conversations around religion and spirituality. Incorporating chapters on ways of religious and spiritual being from Bringing Religion and Spirituality into Therapy: A Process-based Model for Pluralistic Practice (Stewart-Sicking et al. 2019) would aid in this vital form of knowledge. Additionally, the classic Varieties of Religious Experience: A Study in Human Nature by William James (James 2021) still documents the deep intersections of psychology, sociology, with a wide manifestation of religion and spirituality in different personalities and experiences, that would equip students and seasoned therapists to work with a wide range of religious expressions.

However, coursework and electives on religion and spirituality within training programs will likely struggle with self-selection bias. Logistically, it may be difficult for faculty to build up a baseline curriculum in some of the themes and theoretical insights noted in this paper. Therefore, we advocate for centering discussions of religion and spirituality within all coursework, much like multiculturalism theory. Due to the foundational nature of multiculturalism, religion, and spirituality to human diversity, it is important for educators to have intentional conversations within all their coursework around foundational concepts of wellness and spirituality. As wellness becomes more diverse and open to different traditions (Gamby et al. 2021), educators can utilize our contemporary moment to introduce religion and spirituality intentionally into wellness conversations.

Second, religion and spirituality must be taught and understood within a wider and more complex context of secularization. This vital context will aid in how students and practitioners understand the process of buffering/disembedding and the impact that has on developing clinical and professional relationships. For example, teaching theories of faith development such as Fowler's (1981), could help guide students such as Jordan, in understanding their experiences with buffering and disembedding. Fowler's 5th stage, Conjunctive faith for example, is marked by diversity, knowledge, and a special, spiritual intimacy that develops with knowing and knowledge. This stage helps reconcile diverse value systems and paradoxes into a coherent framework that integrates with religion and spirituality in a harmonious fashion. This developmental stage is healthy, and can potentially help clients and students move past the binary notions that mark our contemporary politicization of religion. This developmental stage can also help nonreligious and secular professionals/educators encourage faith development within their clients/students who are interested in such, and help meet their diverse needs. As noted with Adams et al. (2014), this would also help reconcile faculty's lack of knowledge around religion/spirituality by moving from their disinterest, to interest, as it gives them a stake in the healthy development of their students. Furthermore, Fowler's 6th stage, Universalizing Faith, is marked by religious and spiritual figures transcending ego attachments and becoming true servants of humanity. This form of sainthood is congruent with many types of mysticism found within traditional religions, and can help students and professionals conceptualize how forms of ascetism, detachment, and pro-social behavior are found within diverse individuals of different religions and spiritualties, around the world. This last stage is congruent with well-established ethical and teaching standards around social justice, and can address concerns around the secular institution's integrity and potentially alleviate faculty bias (Adams et al. 2014).

While Fowler's developmental theory is congruent with psychological models, it remains limited in describing forms of religious/spiritual pluralism that inevitably manifest within diverse student and professional bodies. Indeed, Fowler's 6th stage of universalizing faith may be a helpful in promoting an integration of social justice with religion and spirituality. However, universalizing religion and spirituality can inevitably flatten the individual diversity and contradictions between divergent world-views, theologies, and flexible spiritualties. In order to build space where diversity of worldviews and spiritualties are accepted, along with tolerance for dissent, Heim (1995) argues for three different orientations to religion and spirituality to be discussed and processed. The first 
is exclusionism, where a religion/spirituality is able to claim its own unique worldview as being the best path towards Truth. The second, is inclusive, where various forms of religions and spiritualities are flattened to be ultimately the same expression of universal Truth. Lastly, pluralism as articulated by Heim, involves attention to the unique and often contradictory religious/spiritual dimensions that have their own specific paths and ideas of Truth, salvation, and living a good life. This specific form of pluralism allows for every religion to be seen as its own path with specific demands, and that can be learned from and shared with a wider audience, while still keeping its worldview and commitments intact. Educators and professionals shifting from developmental stages of Fowler, to more pluralistic conceptions of religious/spiritual difference as articulated by Heim, creates a dialectal space where commitment to affiliation can be upheld, but also diversity can be shared and learned from. This attention to pluralism would help eliminate reductionist ideas of religion and spirituality that are inevitably reproduced through institutions, as articulated by Asad (2003). These three basic orientations also allow professionals in practice to locate their clients in one of these orientations, and help them meet them where they are, rather than attempting to flatten or push them to a certain religious/spiritual perspective.

Additionally, robust knowledge and discussions around concepts of orthodoxy and orthopraxy, along with exoteric and esoteric concepts of religion and spirituality, would equip the therapist and the supervisor in both vignettes with the ability to add rigor and nuance to their case conceptualizations. Further, familiarizing oneself with the idea of disenchantment, can illuminate how contemporary society has evolved to regard all forms of knowledge, not only religion and spirituality, through specific lenses. This can be accomplished through re-enchanting or viewing religion and spirituality as providing more than just its fundamental, measurable essences of creedal-belief and coping. Thus, professionals will be better equipped to build meaningful, professional relationships with their clients around other manifestations of religion and spirituality, such as how this process imposes moral demands, or how ascetic practices provide forms of knowledge and insight.

Lastly, practitioners, educators, and students, will be better equipped to interact with a diverse society, full of complex and beautiful religious and spiritual traditions. An overtly reductionist view encourages co-opting and commodification of ancient religious and spiritual practices that are divorced from their internal cosmology and ideologically incoherent (Arjana 2020; Purser 2019).

Author Contributions: Not an empirical article. All authors contributed based on their agreed upon author order and approve of the final product before submission. All authors have read and agreed to the published version of the manuscript.

Funding: This research received no external funding.

Institutional Review Board Statement: Not Applicable.

Informed Consent Statement: Not Applicable.

Data Availability Statement: No data required.

Conflicts of Interest: The authors declare no conflict of interest.

\section{References}

Adams, Christopher M., Ana Puig, Adrienne Baggs, and Cheryl P. Wolf. 2014. Integrating religion and spirituality into counselor education: Barriers and strategies. Counselor Education and Supervision 54: 44-56. [CrossRef]

Allmon, Allison L. 2013. Religion and the DSM: From pathology to possibilities. Journal of Religion and Health 52: 538-49. [CrossRef]

American Psychological Association (APA). 2015. Commission on Accreditation: Implementing Regulations Related to the Standards of Accreditation. Available online: http:/ / www.apa.org/ed/accreditation/section-c-soa.pdf (accessed on 8 May 2021).

American Psychiatric Association. 2013. Diagnostic and Statistical Manual of Mental Disorders, 5th ed. Arlington: American Psychiatric Association.

Ammerman, Nancy T. 2013. Spiritual but not religious? Beyond binary choices in the study of religion. Journal for the Scientific Study of Religion 52: 258-78. [CrossRef]

Anekstein, Alyse M., Lynn Bohecker, Tiffany Nielson, and Hailey Martinez. 2018. Godspeed: Counselor education doctoral student experiences from diverse religious and spiritual backgrounds. The Qualitative Report 23: 2862-82. [CrossRef] 
Arjana, Sophia Rose. 2020. Buying Buddha, Selling Rumi: Orientalism and the Mystical Marketplace. London: Oneworld Academic.

Asad, Talal. 2003. Formations of the Secular: Christianity, Islam, Modernity (Cultural Memory in the Present), 1st ed. Redwood City: Stanford University Press.

Association for Spiritual, Ethical, and Religious Values in Counseling (ASERVIC). 2009. Competencies for Addressing Spiritual and Religious Issues in Counseling. Available online: https://www.counseling.org/docs/default-source/competencies/competenciesfor-addressing-spiritual-and-religious-issues-in-counseling.pdf?sfvrsn=aad7c2c_8\$ $\backslash$ backslash\$ (accessed on 8 May 2021).

Brawer, Peter A., Paul J. Handal, Anthony N. Fabricatore, Rafael Roberts, and Valerie A. Wajda-Johnston. 2002. Training and education in religion/spirituality within APA accredited psychology programs. Professional Psychology, Research and Practice 33: 203-6. [CrossRef]

Calhoun, Craig C. 2010. Rethinking secularism. The Hedgehog Review 12: 35-48. Available online: http://eprints.1se.ac.uk/42624/ (accessed on 8 May 2021).

Captari, Laura E., Joshua N. Hook, William Hoyt, Don E. Davis, Stacey E. McElroy-Heltzel, and Everett L. Worthington Jr. 2018. Integrating clients' religion and spirituality within psychotherapy: A comprehensive meta-analysis. Journal of Clinical Psychology 74: 1938-51. [CrossRef]

Cashwell, Craig S., and J. Scott Young. 2014. Integrating Spirituality and Religion into Counseling: A Guide to Competent Practice. Hoboken: John Wiley \& Sons.

Commission on Accreditation for Marriage and Family Therapy Education (COAMFTE). 2016. Accreditation Standards: Graduate E PostGraduate Marriage and Family Therapy Training Programs. Available online: https:/ / www.coamfte.org/Documents/COAMFTE/ Version\%2012/COAMFTE_Accreditation_Standards_Version_12.pdf (accessed on 8 May 2021).

Cornish, Marilyn A., Nathaniel G. Wade, and Brian C. Post. 2012. Attending to religion and spirituality in group counseling: Counselors' perceptions and practices. Group Dynamics: Theory, Research, and Practice 16: 122-37. Available online: https://doi-org.proxy.library. vcu.edu/10.1037/a0026663 (accessed on 8 May 2021). [CrossRef]

Council for Accreditation of Counseling and Related Educational Programs (CACREP). 2015. 2016 CACREP Standards. Available online: http:/ / www.cacrep.org/wp-content/uploads/2018/05/2016-Standards-with-Glossary-5.3.2018.pdf (accessed on 8 May 2021).

Council on Social Work Education (CSWE). 2015. Educational Policy and Accreditation Standards for Baccalaureate and Master's Social Work Programs. Available online: http:/ / www.cswe.org (accessed on 8 May 2021).

Currier, Joseph M., Ryon C. McDermott, Laura T. Stevens, Steven L. Isaak, Edward B. Davis, William-Glenn L. Hollingsworth, and Tres Stefurak. 2021. A practice-based evidence investigation of God representations in spiritually integrated psychotherapies. Journal of Clinical Psychology 77: 1018-33. [CrossRef] [PubMed]

Delaney, Harold D., William R. Miller, and Ana M. Bisonó. 2013. Religiosity and spirituality among psychologists: A survey of clinician members of the American Psychological Association. Professional Psychology: Research and Practice 38: 538. [CrossRef]

Demir, Emre. 2019. The evolution of spirituality, religion and health publications: Yesterday, today and tomorrow. Journal of Religion and Health 58: 1-13. [CrossRef] [PubMed]

Diallo, Abdoulaye, M. Herold, L. Diallo, I. Marini, and A. Dominguez. 2021. Clients' willingness to incorporate religion or spirituality in counseling. Rehabilitation Research, Policy, and Education 35: 2-17. [CrossRef]

Dobmeier, Robert A., and Summer M. Reiner. 2012. Spirituality in the counselor education curriculum: A national survey of student perceptions. Counseling and Values 57: 47-65. [CrossRef]

D'Souza, Russeell. 2007. The importance of spirituality in medicine and its application to clinical practice. Medical Journal of Australia 186: S57. [CrossRef]

Ecklund, Elaine Howard, Jerry Z. Park, and Phil Todd Veliz. 2008. Secularization and religious change among elite scientists. Social Forces 86: 1805-39. [CrossRef]

Fowler, James. 1981. Stages of Faith: The Psychology of Human Development and the Quest for Meaning. New York: Harper \& Row.

Gamby, Katie, Dominique Burns, and Kaitlyn Forristal. 2021. Wellness decolonized: The history of wellness and recommendations for the counseling field. Journal of Mental Health Counseling 43: 228-45. [CrossRef]

Hage, Sally M., Amy Hopson, Matthew Siegel, Gregory Payton, and Elizabeth DeFanti. 2006. Multicultural training in spirituality: An interdisciplinary review. Counseling and Values 50: 217-34. [CrossRef]

Hancock, Claire. 2008. Spatialities of the secular: Geographies of the veil in France and Turkey. European Journal of Women's Studies 15: 165-79. [CrossRef]

Heelas, Paul. 2011. Spirituality in the Modern World: Within Religious Tradition and Beyond (Critical Concepts in Religious Studies), 1st ed. Oxfordshire: Routledge.

Heim, Mark. 1995. Salvations: Truth and Difference in Religion (Faith Meets Faith Series). New York: Orbis Books.

Hofmann, Liane, and Harald Walach. 2011. Spirituality and religiosity in psychotherapy-A representative survey among german psychotherapists. Psychotherapy Research 21: 179-92. [CrossRef] [PubMed]

Houtman, Dick, and Stef Aupers. 2007. The spiritual turn and the decline of tradition: The spread of post-christian spirituality in 14 western countries, 1981-2000. Journal for the Scientific Study of Religion 46: 305-20. [CrossRef]

Isaac, Kathleen S., Jennifer L. Hay, and Erica I. Lubetkin. 2016. Incorporating spirituality in primary care. Journal of Religion and Health 55: 1065-77. [CrossRef] [PubMed]

James, William. 2021. Varieties of Religious Experience: A Study in Human Nature. New York: Modern Library. 
Jenkins, Richard. 2000. Disenchantment, enchantment and re-enchantment: Max weber at the millennium. Max Weber Studies 1: 11-32. Available online: http:/ / www.jstor.org/stable/24579711 (accessed on 8 May 2021).

Johns, R. David. 2017. Stories matter: Narrative themes of counselor educators' religious and spiritual competency. Counseling and Values 62: 72-89. [CrossRef]

Josephson-Storm, Jason Ananda Josephson. 2017. The Myth of Disenchantment: Magic, Modernity, and the Birth of the Human Sciences, Illustrated ed. Chicago: University of Chicago Press.

Latour, Bruno, and Catherine Porter. 1993. We Have Never Been Modern. Cambridge: Harvard University Press.

Mahmood, Saba. 2010. Can secularism be other-wise? (A critique of charles taylor's a secular age). In Varieties of Secularism in a Secular Age, 1st ed. Edited by Michael Warner, Jonathan Vanantwerpen and Craig Calhoun. Cambridge: Harvard University Press, pp. $282-99$.

Majumdar, S., and V. Villa. 2020. In 2018, Government Restrictions on Religion Reach Highest Level Globally in More Than a Decade. Washington: Pew Research Center's Religion \& Public Life Project, November 10. Available online: https://www.pewforum.org/ 2020/11/10/in-2018-government-restrictions-on-religion-reach-highest-level-globally-in-more-than-a-decade/ (accessed on 8 May 2021).

National Secular Society. 2017. What is Secularism? National Secular Society. Available online: https://www.secularism.org.uk/whatis-secularism.html (accessed on 8 May 2021).

O'Connor, Shawn, and Brian Vandenberg. 2005. Psychosis or faith? Clinicians' assessment of religious beliefs. Journal of Consulting and Clinical Psychology 73: 610-16. [CrossRef] [PubMed]

Oxhandler, Holly. K., and Danielle E. Parrish. 2018. Integrating clients' religion/spirituality in clinical practice: A comparison among social workers, psychologists, counselors, marriage and family therapists, and nurses. Journal of Clinical Psychology 74: 680-94. [CrossRef] [PubMed]

Oxhandler, Holly K., Danielle E. Parrish, Luis R. Torres, and W. Andrew Achenbaum. 2015. The integration of clients' religion and spirituality in social work practice: A national survey. Social Work 60: 228-37. [CrossRef] [PubMed]

Perry, William G. 1970. Forms of Ethical and Intellectual Development in the College Years. Hoboken: Wiley.

Pew Research Center. 2019. In U.S., Decline of Christianity Continues at Rapid Pace. Washington: Pew Research Center's Religion \& Public Life Project, October 17. Available online: https:/ / www.pewforum.org/2019/10/17/in-u-s-decline-of-christianity-continues-atrapid-pace/ (accessed on 8 May 2021).

Pew Research Center. 2021. Measuring Religion in Pew Research Center's American Trends Panel. Washington, DC: Pew Research Center's Religion \& Public Life Project, January 14. Available online: https:/ /www.pewforum.org/2021/01/14/measuring-religion-inpew-research-centers-american-trends-panel/ (accessed on 8 May 2021).

Post, Brian C., and Nathaniel G. Wade. 2009. Religion and spirituality in psychotherapy: A practice-friendly review of research. Journal of Clinical Psychology 65: 131-46. [CrossRef]

Post, Brian C., Nathaniel G. Wade, and Marilyn A. Cornish. 2014. Religion and spirituality in group counseling: Beliefs and preferences of university counseling center clients. Group Dynamics: Theory, Research, and Practice 18: 53-68. [CrossRef]

Purser, Ronald. 2019. McMindfulness: How Mindfulness Became the New Capitalist Spirituality. London: Repeater.

Putnam, Robert D., and David E. Campbell. 2012. American Grace: How Religion Divides and Unites Us. New York: Simon \& Schuster.

Robertson, Linda A. 2010. The spiritual competency scale. Counseling and Values 55: 6-24. [CrossRef]

Rupert, David, Sarah H. Moon, and Steven J. Sandage. 2019. Clinical training groups for spirituality and religion in psychotherapy. Journal of Spirituality in Mental Health 21: 163-77. [CrossRef]

Saroglou, Vassilis. 2020. The Psychology of Religion (The Psychology of Everything), 1st ed. Oxfordshire: Routledge.

Schafer, Rachel M., Paul J. Handal, Peter A. Brawer, and Megan Ubinger. 2011. Training and education in religion/spirituality within APA-accredited clinical psychology programs: 8 years later. Journal of Religion and Health 50: 232-39. [CrossRef] [PubMed]

Scott, Stephanie K., Donna S. Sheperis, Robyn Trippany Simmons, Tiffany Rush-Wilson, and Loria A. Milo. 2016. Faith as a cultural variable: Implications for counselor training. Counseling and Values 61: 192-205. [CrossRef]

Singh, Vijendra. 2019. Relationship between the spiritual and the secular: Vivekananda, Gandhi and Radhakrishnan. Studies in Indian Politics 7: 56-69. [CrossRef]

Somer, Murat. 2013. Is turkish secularism antireligious, reformist, separationist, integrationist, or simply undemocratic? Journal of Church and State 55: 585-97. [CrossRef]

Souza, Katherine Z. 2002. Spirituality in counseling: What do counseling students think about it? Counseling and Values 46: 213-17. [CrossRef]

Stewart-Sicking, Joseph A., J. Fox, and Paul. J. Deal. 2019. Bringing Religion and Spirituality into Therapy: A Process-Based Model for Pluralistic Practice, 1st ed. London: Routledge.

Stewart-Sicking, Joseph A., Paul J. Deal, and Jesse Fox. 2017. The ways paradigm: A transtheoretical model for integrating spirituality into counseling. Journal of Counseling \& Development 95: 234-41. [CrossRef]

Taylor, Charles. 2018. A Secular Age, Reprint ed. Cambridge: Belknap Press, An Imprint of Harvard University Press.

Thalheimer, Fred. 1973. Religiosity and secularization in the academic professions. Sociology of Education, 183-202. [CrossRef]

Vieten, Cassandra, Shelley Scammell, Alan Pierce, Ron Pilato, Ingrid Ammondson, Kenneth I. Pargament, and David Lukoff. 2016. Competencies for Psychologists in the Domains of Religion and Spirituality. Spirituality in Clinical Practice 3: 92-114. [CrossRef]

Walker, Donald F., Richard L. Gorsuch, and Siang-Yang Tan. 2004. Therapists' integration of religion and spirituality in counseling: A meta-analysis. Counseling and Values 49: 69-80. [CrossRef] 
Weber, Max, and Ephraim Fischoff. 1993. The Sociology of Religion, 2nd ed. Boston: Beacon Press.

Weber, Max, and Talcott Parsons. 2017. The Protestant Work Ethic and the Spirit of Capitalism. Cambridge: Vigeo Press.

Weber, Max, Paul Reitter, Chad Wellmon, and Damion Searls. 2020. Charisma and Disenchantment: The Vocation Lectures (New York Review Books Classics). London: NYRB Classics.

Young, J. Socct, Marsha Wiggins-Frame, and Craig S. Cashwell. 2007. Spirituality and counselor competence: A national survey of American Counseling Association members. Journal of Counseling E Development 85: 47-52. [CrossRef] 